\title{
Correction to: Andean potato diversity conserved in the International Potato Center genebank helps develop agriculture in Uganda: the example of the variety 'Victoria'
}

\author{
Vivian Bernal-Galeano ${ }^{1} \cdot$ George Norton ${ }^{1} \cdot$ David Ellis $^{2} \cdot$ Noelle L. Anglin $^{2} \cdot$ Guy Hareau $^{2} \cdot$ Melinda Smale $^{3}$ (D) \\ Nelissa Jamora ${ }^{4}$. Jeffrey Alwang ${ }^{1} \cdot$ Willy Pradel $^{2}$
}

Published online: 12 January 2021

(C) The Author(s) 2021

Correction to: Food Security (2020) 12(5):959-973 https://doi.org/10.1007/s12571-020-01037-8

The article "Andean potato diversity conserved in the International Potato Center genebank helps develop agriculture in Uganda: the example of the variety 'Victoria'", written by Vivian Bernal-Galeano, George Norton, David Ellis, Noelle L. Anglin, Guy Hareau, Melinda Smale, Nelissa Jamora, Jeffrey Alwang, and Willy Pradel, was originally published Online First without Open Access. After publication in volume 12, issue 5, page 959-973 the author decided to opt for Open Choice and to make the article an Open Access publication. Therefore, the copyright of the article has been changed to () The Authors 2021 and the article is forthwith distributed under the terms of the Creative Commons Attribution 4.0 International License, which permits use, sharing, adaptation, distribution and reproduction in any medium or format, as long as you give appropriate credit to the original author(s) and the source, provide a link to the Creative Commons licence, and indicate if changes were made. The images or other third party material in this article are included in the article's Creative Commons licence, unless indicated otherwise in a credit line to the material. If material is not included in the article's Creative Commons licence and your intended use is not permitted by statutory regulation or exceeds the permitted use, you will need to obtain permission directly from the copyright holder. To view a copy of this licence, visit https://creativecommonshorg/licenses/by/4.0/.

The original article has been corrected.

Open Access This article is licensed under a Creative Commons Attribution 4.0 International License, which permits use, sharing, adaptation, distribution and reproduction in any medium or format, as long as you give appropriate credit to the original author(s) and the source, provide a link to the Creative Commons licence, and indicate if changes were made. The images or other third party material in this article are included in the article's Creative Commons licence, unless indicated otherwise in a credit line to the material. If material is not included in the article's Creative Commons licence and your intended use is not permitted by statutory regulation or exceeds the permitted use, you will need to obtain permission directly from the copyright holder. To view a copy of this licence, visit http://creativecommons.org/licenses/by/4.0/.

The online version of the original article can be found at https://doi.org/ 10.1007/s12571-020-01037-8

Melinda Smale

msmale@msu.edu

Nelissa Jamora

nelissa.jamora@croptrust.org

1 Virginia Tech, Blacksburg, VA, USA

2 International Potato Center, Lima, Peru

3 Michigan State University, East Lansing, VA, USA

4 Global Crop Diversity Trust (Crop Trust), Bonn, Germany 